\title{
Large scale modeling of the transport, chemical transformation and mass budget of the sulfur emitted during the April 2007 eruption of Piton de la Fournaise
}

\author{
P. Tulet ${ }^{1,2}$ and N. Villeneuve $\mathrm{e}^{3,4}$ \\ ${ }^{1}$ LACy, UMR8105, CNRS - Université de La Réunion, Météo-France, 15 avenue René Cassin, 97715 Saint-Denis Messag., \\ France \\ ${ }^{2}$ CNRM/GAME, URA1357, CNRS - Météo-France, 42, Avenue Gaspard Coriolis, 31057 Toulouse, France \\ ${ }^{3}$ US140 ESPACE, Centre IRD de La Réunion, BP172, 97492 Saint-Denis, France \\ ${ }^{4}$ LGSR, UMR7154, CNRS - Université de La Réunion, IPGP, 15 avenue René Cassin, 97715 Saint Denis cedex 9, France
}

Received: 15 July 2010 - Published in Atmos. Chem. Phys. Discuss.: 8 September 2010

Revised: 3 May 2011 - Accepted: 8 May 2011 - Published: 12 May 2011

\begin{abstract}
In April 2007, the Piton de la Fournaise volcano (Réunion island) entered into its biggest eruption recorded in the last century. Due to the absence of a sensors network in the vicinity of the volcano, an estimation of degassing during the paroxysmal phase of the event has not been performed. Nevertheless, the $\mathrm{SO}_{2}$ plume and aerosols have been observed by the OMI and CALIOP space sensors, respectively. The mesoscale chemical model MesoNH-C simulates the observed bulk mass of $\mathrm{SO}_{2}$ and the general shape of the $\mathrm{SO}_{2}$ plume spreading over the Indian Ocean. Moreover, an analysis of the $\mathrm{SO}_{2}$ plume budget estimates a total $\mathrm{SO}_{2}$ release of $230 \mathrm{kt}$, among of which $60 \mathrm{kt}$ have been transformed into $\mathrm{H}_{2} \mathrm{SO}_{4}$. $27 \mathrm{kt}$ of $\mathrm{SO}_{2}$ and $21 \mathrm{kt}$ of $\mathrm{H}_{2} \mathrm{SO}_{4}$ have been deposited at the surface by dry deposition. With this top down approach, the temporal evolution of the $\mathrm{SO}_{2}$ emission has been estimated during the most active period of the eruption. The peak of degassing was estimated at $1800 \mathrm{~kg} \mathrm{~s}^{-1}$ in the morning of 6 April. The temporal evolution of $\mathrm{SO}_{2}$ emission presented here can also be used for local studies.
\end{abstract}

\section{Introduction}

Volcanoes represent one of the most significant natural sources of pollutants in the atmosphere, both during and between eruptions (Mather et al., 2005). Large explosive eruptions such as El Chichòn in 1982 (Pollack et al., 1983; Hoff-

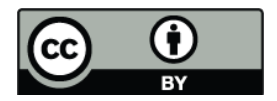

Correspondence to: P. Tulet

(pierre.tulet@univ-reunion.fr) man, 1987) or Mount Pinatubo in 1991 (McCormick et al., 1995; Robock, 2002) have highlighted their impacts on the earth's radiative balance through the injection of large quantities of aerosol into the troposphere and the lower stratosphere (Delmelle et al., 2002; Oppenheimer et al., 2003; Arellano et al., 2008). In addition, volcanic emissions can also cause serious perturbations in air traffic as has happened recently during Eyjafjallajökull's 2010 eruption in Iceland (Seifert et al., 2010). For these reasons, the understanding and forecasting of the volcanic plumes are still major challenges for atmospheric sciences and risk mitigation.

In the atmosphere science of volcanic plumes, sulfur dioxides $\left(\mathrm{SO}_{2}\right)$ is the most commonly measured gas (Thomas et al., 2009). Resulting from the oxidation of sulfur present in the magma, the degassing of $\mathrm{SO}_{2}$ is a robust indicator of eruptive activity and sheds light on magma storage (Edmonds et al., 2003; Sutton et al., 2001). In the atmosphere, oxidation of $\mathrm{SO}_{2}$ into sulfuric acid forms aerosols by homogeneous nucleation (Kulmala et al., 1998) or condensation on preexisting aerosols (Seinfeld and Pandis, 2006; Martin et al., 2008; Stevenson et al., 2003). Through aqueous processes, $\mathrm{SO}_{2}$ can also form acid rain (Hoffman et al., 1985; Stevenson et al., 2003). On the global scale, Penner et al. (2001) have estimated that the source of volcanic sulfur in the atmosphere ranges from 6 to $20 \mathrm{Tg}$ of sulfur per year $\left(\mathrm{TgS} \mathrm{yr}^{-1}\right)$. This amount of release is non-negligible compared to the anthropogenic fluxes estimated between 70 and $100 \mathrm{TgS} \mathrm{yr}^{-1}$, which corresponds to $70 \%$ of the total sulfur emissions.

For many years, satellite-based measurements of volcanic $\mathrm{SO}_{2}$ emissions were limited to major eruptions linked to large production of $\mathrm{SO}_{2}$ and big plumes (Carn et al., 2008).

Published by Copernicus Publications on behalf of the European Geosciences Union. 
Until recently, most measurements of volcanic $\mathrm{SO}_{2}$ fluxes between two eruption events, or measurements of effusive volcanoes, were based on ground or airborne instrumentation (Carn et al., 2007). Even though most space-based $\mathrm{SO}_{2}$ measurements were useful for volcanic hazard mitigation (including aviation consequences) and for tracking volcanic clouds (Krueger et al., 1995; Afe et al., 2004; Khokhar et al., 2005), a significant advance was introduced with recently launched sensors (Carn et al., 2008).

In this context, the amount of $\mathrm{SO}_{2}$ released into the atmosphere by the eruption of Piton de la Fournaise in April 2007 at La Réunion needs to be estimated for two reasons. First, Piton de la Fournaise is one of the world's most active volcanoes (Lenat and Bachelery, 1987) with an average of one eruption every eight months in the last fifty years (Peltier et al., 2009). Secondly, the April 2007 eruption is the largest eruption of Piton de la Fournaise in at least one century (Deroussi et al., 2009). At least 180 million $\mathrm{m}^{3}$ of lava was estimated to be produced during this eruption (of which half stayed on the Le Grand Brûlé area; Staudacher et al., 2009, and half went into the sea; Saint-Ange, 2009).

Most of the time, the eruptions of the Piton de la Fournaise do not produce significant quantities of ash and sulfur. In the literature, only few examples reference such activity, most often associated with historic caldera collapses. This kind of activity has been observed from the presence of volcanic ash rather than sulfur. Khokhar et al. (2005), Bhugwant et al. (2008) and Staudacher et al. (2009) are the only references to an observed plume rich in sulfur that was produced by an eruption of Piton de la Fournaise. Except in urban areas, no ground instruments continuously measured $\mathrm{SO}_{2}$ during the paroxysmal stage of the eruption. As a consequence, the sulfur degassing of Piton de la Fournaise has not been estimated. The main objective of this study is to estimate the $\mathrm{SO}_{2}$ release using both large scale satellite observations and a top-down modeling approach. This paper is an extension of preliminary $\mathrm{SO}_{2}$ mass estimates published on-line during and just after the April 2007 eruption, using the OMI, SCIAMACHY and GOME2 sensors (http: //so2.umbc.edu/omi/pix/special/2007/piton/piton04.php and http://sacs.aeronomie.be).

This paper is organized as follows. Section 2 focuses on the eruption phenomenon. An analysis of the $\mathrm{SO}_{2}$ plumes observed by satellites is given in Sect. 3. Then, the numerical methods (Sect. 4) and the simulation results (Sect. 5) are presented. The last section is devoted to quantifying the mass budget of the volcanic sulfur and to estimate the $\mathrm{SO}_{2}$ emitted during the main eruptive period.

\section{Description of the Piton de la Fournaise volcano eruption (April 2007)}

The 2 April 2007 eruption is the largest eruption of Piton de la Fournaise volcano on Réunion island in at least one century (Deroussi et al., 2009). The associated collapse of the summit caldera caused significant morphological change (Michon et al., 2007). Due to this abnormal phenomenon and its large impact on the environment and on civil protection policy, this eruption is very well described in literature. The most important phases are summarized below.

The 2 April 2007 eruption was preceded by two short eruptive events (lasting only a few hours) on 18 February and on 30 March. At 06:00 UTC on 2 April, a new eruption started along a $1 \mathrm{~km}$ long fissure, located on the lower south-eastern part of the Enclos (called Le Grand Brûlé) at only $590 \mathrm{~m}$ above sea level (a.s.1.), $7 \mathrm{~km}$ away from the summit and $3 \mathrm{~km}$ from the coast. The beginning of the 2 April 2007 eruption was characterized by $50 \mathrm{~m}$ high continuous lava fountains feeding voluminous lava flows (Michon et al., 2007). The Observatoire Volcanologique du Piton de la Fournaise recorded high seismicity related to the opening of the eruptive fissure (Staudacher et al., 2009). For a few hours on 3 April activity dramatically decreased before gradually resuming until it reached a maximum at mid-day on 6 April. This period was observed by remote sensing instruments. In fact, Coppola et al. (2009) estimated a significant increase of the lava flow rate between the 3 April and the 5 April, from 55 to $75 \mathrm{~m}^{3} \mathrm{~s}^{-1}$, by radiance analyses of the MODIS sensors. The first consequence of the vent location near the coast is the rapid and early entrance of the lava flow into seawater. This produced a large acid water vapour plume $(\mathrm{pH}<2)$, rich in chlorine and sulfur (Staudacher et al., 2009). On 5 April at 20:48 UTC, an earthquake of magnitude 3.2 coincided with the onset of a caldera collapse (Michon et al., 2007). A geodetic network recorded an inward deformation prior to the earthquake, followed by a sudden outward displacement of 10-20 cm (Peltier et al., 2009). From 20:48 UTC on 5 April until 00:00 UTC on 7 April, the nature of the activity changed (Michon et al., 2007). Analysis of geophysical network signals allowed the determination of cycles characterized by variations in seismic activity and by deformation (progressive inward displacement ending in a strong outward motion) (Michon et al., 2007, 2009; Staudacher et al., 2009; Peltier et al., 2009). These authors interpreted such cycles as a result of pressure variations in the magma chamber causing a subsequential formation of the caldera. Output flow rates (greater than $200 \mathrm{~m}^{3} \mathrm{~s}^{-1}$ ) have been estimated by field observations, with a maximum during 6 April (Coppola et al., 2009). Observations clearly showed that the maximum activity at the eruption location (higher degassing, higher lava fountains and higher output flow rate) coincided with a higher seismic activity signature.

Figure 1 illustrates the volcanic event during the maximum stage. Figure 1a and $\mathrm{b}$ shows the evolution between the afternoon of 5 April (Fig. 1a) when the activity increased and the afternoon of 6 April (Fig. 1b) at the collapse of the caldera. For the Fig. 1c, the camera was installed near the Piton des Neiges summit, $27 \mathrm{~km}$ from Piton de la Fournaise summit and $37 \mathrm{~km}$ from the coast at Le Grand Brûlé. The ash plume 

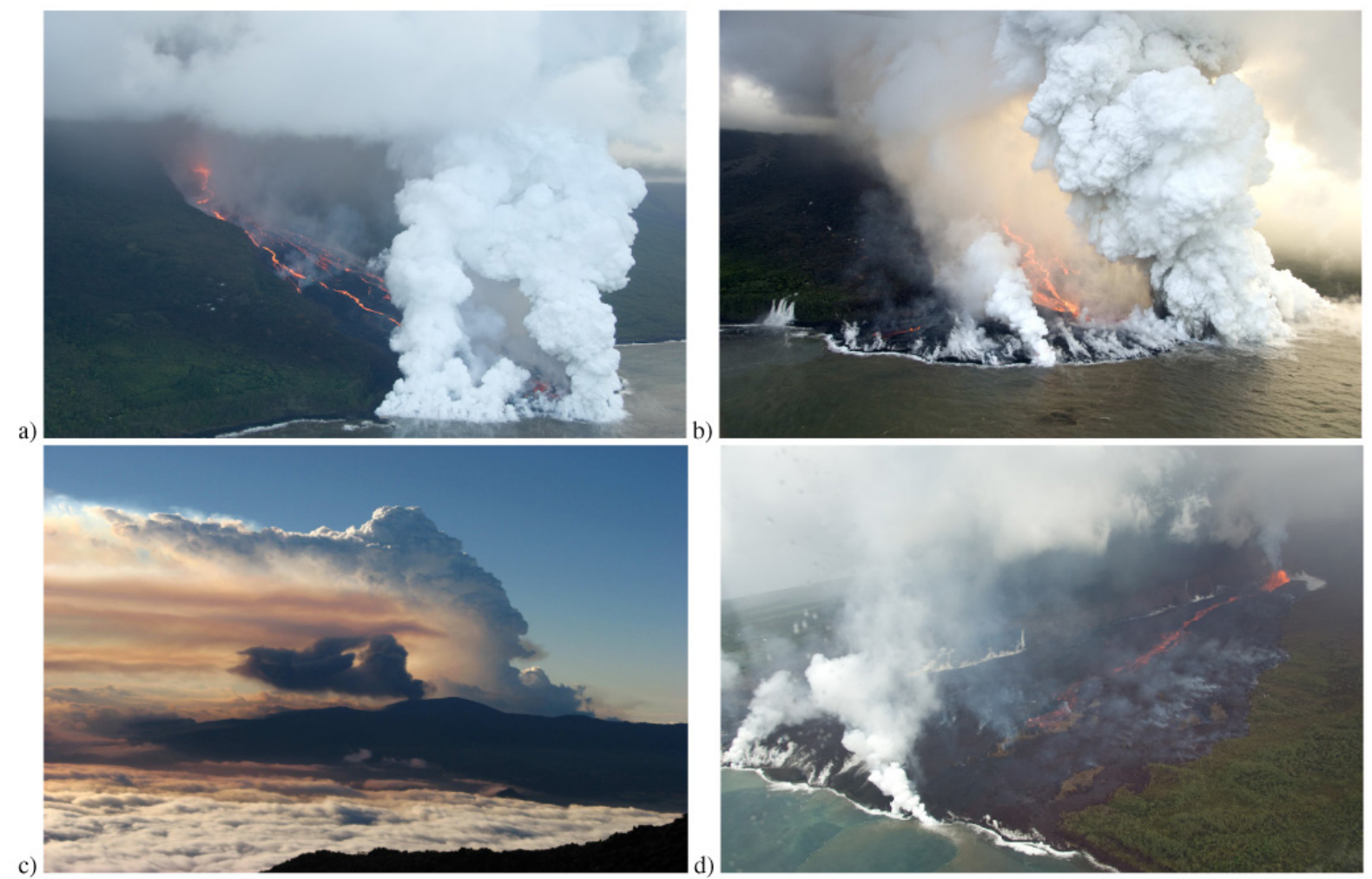

Fig. 1. (a, b and d): lava flow on Le Grand Brûlé area near the Piton Tremblet crater on 5, 6 and 8 April 2007, respectively. Copyright F. Caillé. (c): three different plumes over the Piton de la Fournaise during the collapse of the Dolomieu crater on 6 April 2007. Copyright R. Delmas.

(gray) close to Piton de la Fournaise summit is associated to one of the caldera collapses. Note that this ash plume has a relatively small extent. Furthermore the location of this ash plume is well separated from the $\mathrm{SO}_{2}$ one. This is due to the fact that the $\mathrm{SO}_{2}$ emission is linked to the degassing of the lava flow which started several kilometers from the crater. As observed in Fig. 1c, the $\mathrm{SO}_{2}$ plume (orange) spreads out at a constant altitude. The water vapour plume (white) is a result of the lava flow entering into the sea. Note on Fig. 1d that the volcanic activity dramatically decreases and the lava flow reaches its maximum lateral and longitudinal extents. This stage of the eruption became more "typical" compared to usual eruptions of Piton de la Fournaise. On 10 April between 08:00 and 11:00 UTC a rapid decrease in seismicity was followed by an 8-h break. From 19:00 UTC activity resumed. On 12 April between 11:00 and 14:00 UTC a new collapse occurs with a high output flow rate and a small ash plume dispersion. Subsequently, activity remained stable until the end of the eruption. On 28 April, severals days after the paroxysmal stage, the Observatoire Réunionais de l'Air (ORA) measured $2500 \mu \mathrm{g} \mathrm{m}^{-3}$ of $\mathrm{SO}_{2}$ in the village of Le Tremblet, which is located close to the volcano (Bhugwant et al., 2008).

\section{Large scale transport of $\mathrm{SO}_{2}$}

\subsection{Total column from OMI}

OMI, onboard EOS/Aura, is an hyperspectral UV/Visible spectrometer with a $2600 \mathrm{~km}$ swath and a $13 \times 24 \mathrm{~km}^{2}$ (at nadir) footprint size. Since July 2004, it allows a daily and contiguous global mapping of ozone and trace gases including $\mathrm{SO}_{2}, \mathrm{NO}_{2}$, and $\mathrm{BrO}$ (Carn et al., 2007). The retrieval method used in this study follows the algorithm described by Krotkov et al. (2006) and Yang et al. (2009) and has been validated by Krotkov et al. (2008). OMI SO level 2 data products $\left(\mathrm{OMSO}_{2} \mathrm{V003}\right)$ used in our analyses are available on NASA's Goddard Earth Sciences Data and Information Services Center website (http://disc.sci.gsfc. nasa.gov/Aura/data-holdings/OMI/omso2_v003.shtml). For each scene Goddard Earth Sciences Data provides four different estimates of the $\mathrm{SO}_{2}$ column density using two different algorithms. Since $\mathrm{OMSO}_{2} \mathrm{V003}$, the Planetary Boundary Layer (PBL) $\mathrm{SO}_{2}$ columns that correspond to Center of Mass Altitude (CMA) of $900 \mathrm{~m}$ a.s.l. are produced using the Band Residual Divergence (BRD) algorithm (Krotkov et al., 2006). The CMA is characteristic of the a-priori profil shape. The three other different estimates of the column density 

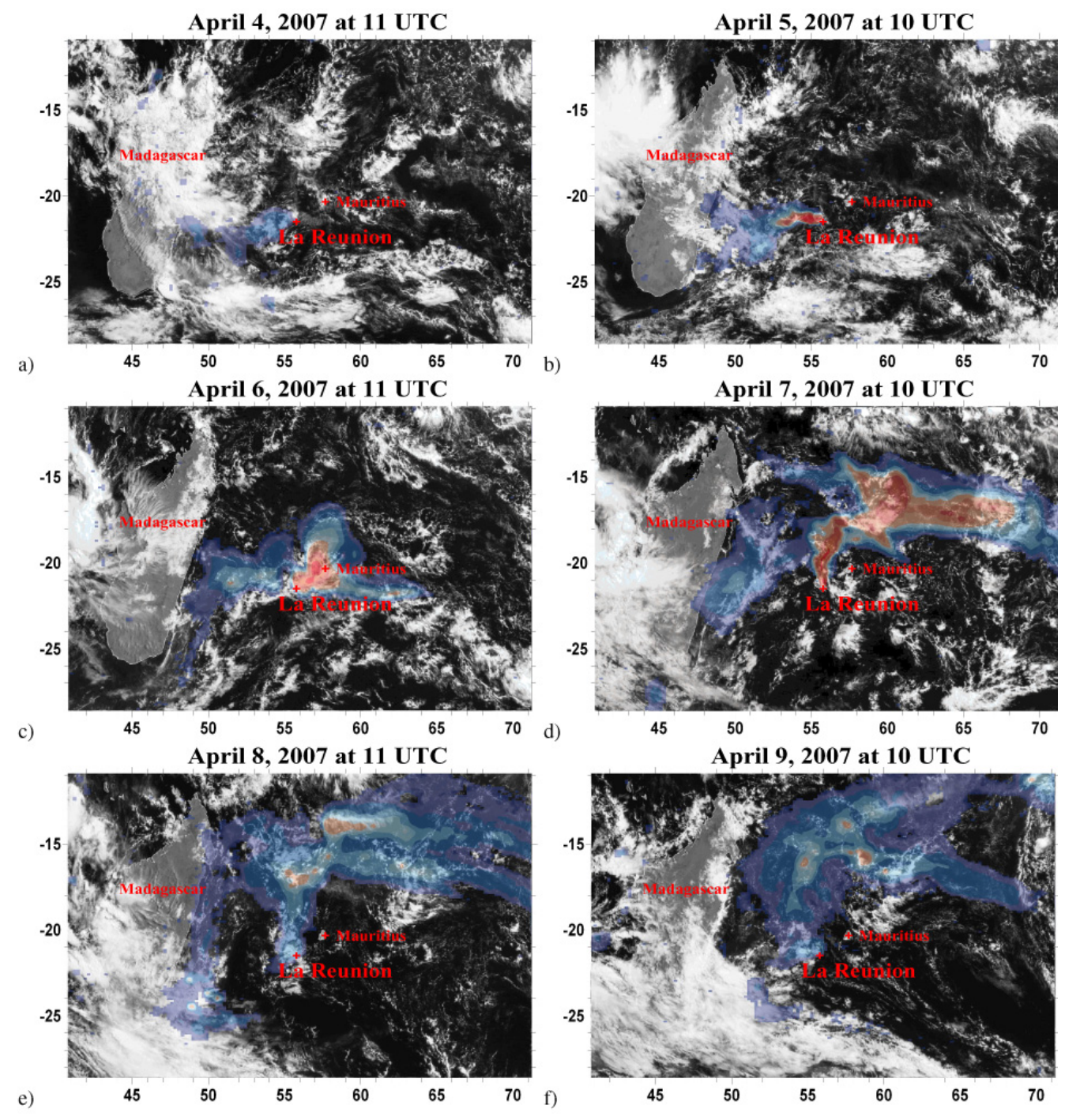

\section{$\mathrm{SO} 2(\mathrm{DU})$}

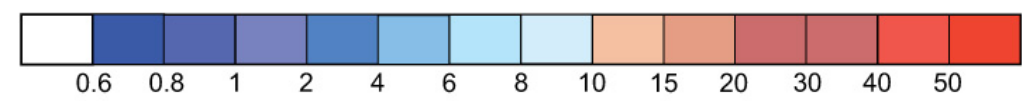

Fig. 2. $\mathrm{SO}_{2}$ mass burden (Dobson Units) measured by OMI superimposed on the Meteosat visible channel, on 4 April at 11:00 UTC (a), 5 April at 10:00 UTC (b), 6 April at 11:00 UTC (c), 7 April at 10:00 UTC (d), 8 April at 11:00 UTC (e) and 9 April at 10:00 UTC (f).

of $\mathrm{SO}_{2}$ are produced with the Linear Fit algorithm (Yang et al., 2007): (i) lower tropospheric level plume (TRL) which corresponds to a CMA of 2500 ma.s.l.; (ii) middle tropospheric level $\mathrm{SO}_{2}$ column (TRM), corresponding to CMA of $7500 \mathrm{~m}$ a.s.l.; and (iii) upper tropospheric and stratospheric (STL), corresponding to CMA of $17000 \mathrm{~m}$ a.s.l.

Figure 2 represents the evolution of the $\mathrm{SO}_{2}$ plume, superimposed on Meteosat 7 satellite images (visible channel) for the period 4 to 9 April 2007. The OMI data products are interpolated by Kriging method on a $13 \times 24 \mathrm{~km}^{2}$ grid.
The domain of interpolation covers a large part of the Indian Ocean $\left(28.6^{\circ} \mathrm{S}-10.9^{\circ} \mathrm{S} ; 40.78^{\circ} \mathrm{E}-71.22^{\circ} \mathrm{E}\right)$. For 4 and 5 April, $\mathrm{SO}_{2}$ burden measurements are determined at the TRL (Fig. 2a and b). For the rest of the eruptive period, a weighted value between TRM and TRL column is used (Fig. 2c-f). These choices are justified by the location of $\mathrm{SO}_{2}$ in the mid-troposphere after 6 April (CMA estimated at $6000 \mathrm{~m}$, see next Section).

The presence of cloudy areas generates uncertainties for $\mathrm{SO}_{2}$ quantification. In these regions, the $\mathrm{SO}_{2}$ burden 
observed in Fig. 2 only corresponds to the mass located over the top of the clouds which can cause an underestimation of the $\mathrm{SO}_{2}$. On the other hand, the cloud albedo can artificially increase the retrieved $\mathrm{SO}_{2}$ values. In some cases pixel values can be negative. Georgoulias et al. (2009) assumed that negative $\mathrm{SO}_{2}$ total column values are linked to a low amount of $\mathrm{SO}_{2}$. As a consequence, the negative values are removed in computations. On 4 April, the $\mathrm{SO}_{2}$ plume observed by OMI at 11:00 UTC is low, reaching 1 Dobson Unit (1 DU corresponding to $2.68 \times 10^{16}$ molecules $\mathrm{cm}^{-2}$ ) and spreading about $2^{\circ}$ west from La Réunion. The $\mathrm{SO}_{2}$ increases on 5 April at 10:00 UTC, up to $70 \mathrm{DU}$ (locally reaching $200 \mathrm{DU}$ ) to the west of La Réunion. The $\mathrm{SO}_{2}$ is also advected a large distance to the west, close to the east coast of Madagascar, where the value of $\mathrm{SO}_{2}$ is close to $2 \mathrm{DU}$.

6 April (11:00 UTC) is the day when Piton de la Fournaise's main summit crater (Dolomieu) collapses, and significant quantities of lava are emitted (Sect. 2). Unfortunately, for the quantification of $\mathrm{SO}_{2}$, two constraints have to be considered. First, the satellite track was far from the zenith of the main plume. As a consequence, the footprint size increases to $13 \times 42 \mathrm{~km}^{2}$ and the accuracy of the data is lowered. Second, this day is also marked by the presence of clouds over La Réunion which prevents a complete detection of the $\mathrm{SO}_{2}$ by OMI (Fig. 2c). The maximum value of $12 \mathrm{DU}$ observed in this area is probably largely underestimated and corresponds only to the $\mathrm{SO}_{2}$ located above the clouds. Nevertheless one can note on Fig. 2c that the plume intensifies and spreads toward the west, close to the eastern coast of Madagascar, to the north and to the east of La Réunion, reaching Mauritius (15 DU). Considering that the lower tropospheric trade winds (Diab et al., 2004) are from the southeast, the presence of the plume in the eastern and northern areas around La Réunion indicates that the $\mathrm{SO}_{2}$ plume has been transported above the inversion layer where wind directions are reversed. On 7 April at 10:00 UTC (Fig. 2d), the plume observed by OMI has intensified. It was advected to the north of La Réunion and then moved eastward. The plume is detected at $83^{\circ} \mathrm{E}, 2800 \mathrm{~km}$ far away from Piton de la Fournaise. The integrated column of $\mathrm{SO}_{2}$ is significant, with $50 \mathrm{DU}$ over $\mathrm{La}$ Réunion, $40 \mathrm{DU}$ in the northern branch and about 15-20 DU in the eastern branch at $65^{\circ} \mathrm{E}$. A gap in the plume shape is noticeable over the area north of Mauritius, and is probably due to the presence of clouds. Close to Madagascar a second $\mathrm{SO}_{2}$ (2 DU) plume corresponds to the western branch of the 6 April plume. The size and concentration of the $\mathrm{SO}_{2}$ plume detected far from La Réunion suggest that the $\mathrm{SO}_{2}$ release on 6 April was considerable.

On 8 and 9 April, the plume decreases to a maximum of 7 DU (Fig. 2e) and 12 DU (Fig. 2f), respectively. This second maximum of $12 \mathrm{DU}$ located at $16^{\circ} \mathrm{S}$ and $58^{\circ} \mathrm{E}$ is puzzling given the fact that such strong values are not observed upstream in the plume on 8 April. Thus, it implies that some plumes of $\mathrm{SO}_{2}$ are masked by the presence of clouds. In this latter period, the plume extends over the Indian Ocean from

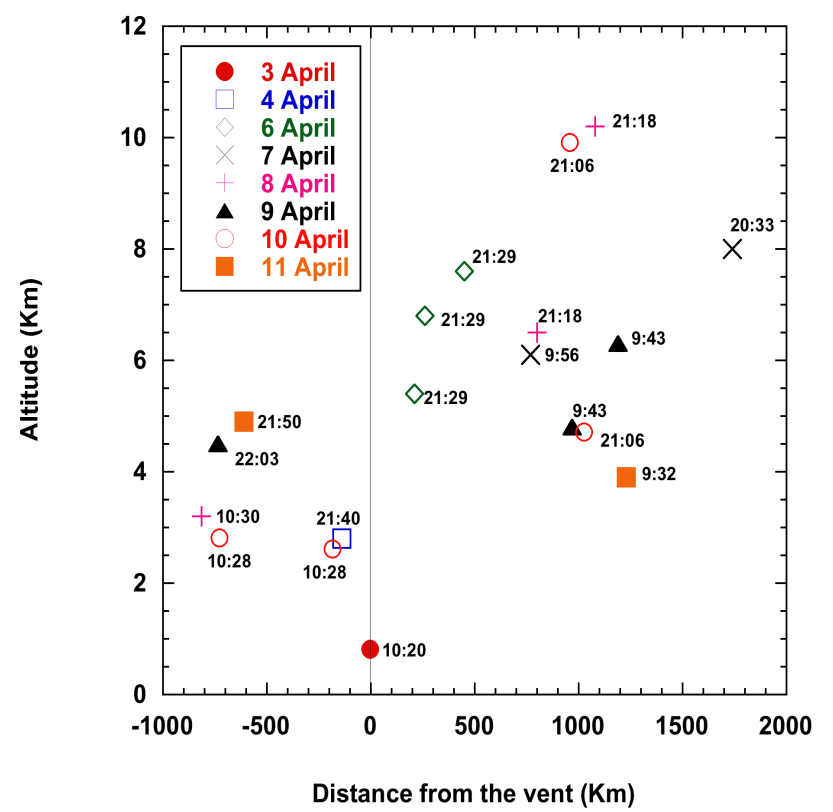

Fig. 3. Altitude and distance from La Réunion of the aerosols plumes observed by the CALIOP sensor on the CALIPSO satellite from 3 April to 11 April 2007 at different times (plotted). Negative abcissa values correspond to the west, and positive values to the east.

$48^{\circ} \mathrm{E}$ on 8 April, to $95^{\circ} \mathrm{E}$ on 9 April (not shown). Above Madagascar, the presence of a cloud system seems to interact with the western part of the plume.

\subsection{Plumes altitudes from CALIPSO}

On the CALIPSO satellite, the Cloud-Aerosol Lidar with Orthogonal Polarization (CALIOP) provides high-resolution vertical profiles (100 $\mathrm{m}$ footprint size) of aerosol and clouds. This sensor allows the discretization of cloud phase and the identification of the presence of non-spherical aerosols (Winker et al., 2003; Carn et al., 2007). CALIPSO completes 14.55 orbits per day with a $24.7^{\circ}$ separation of longitude between each successive orbit at the equator. An analysis of the aerosol plume elevation observed by the different passes of CALIPSO between 2 April and 11 April is reported in Fig. 3 as a function of their distance from La Réunion and their altitude.

Here, it is assumed that the observed aerosol plumes are mainly composed of sulfuric acid $\left(\mathrm{H}_{2} \mathrm{SO}_{4}\right)$. The $\mathrm{SO}_{2}$ in the plume is oxidized into $\mathrm{H}_{2} \mathrm{SO}_{4}$ which then becomes particles through homogeneous nucleation or by deposition on preexisting aerosols (Seinfeld and Pandis, 2006). This assumption is based primarily on the fact that there was no other major source of aerosols over the Indian Ocean during this period, except sea salt in the boundary layer.

Different CALIOP images are available on http://www-calipso.larc.nasa.gov/products/. In this paper, 
in order to select the volcanic aerosol plumes, the following CALIOP images are analysed in the geographic area corresponding to the plume observed with OMI (Fig. 4): (i) $532 \mathrm{~nm}$ Total Attenuated Backscattered, (ii) $1064 \mathrm{~nm}$ Total Attenuated Backscattered, (iii) Vertical Feature Mask, and (iv) Aerosol Subtype. The altitude of the observed plume is directly deduced from the " $532 \mathrm{~nm}$ Total Attenuated Backscattered" picture. On 3 and 4 April, CALIPSO's track observed Piton de la Fournaise's volcanic plumes west of La Réunion below $3000 \mathrm{~m}$ a.s.1. Thus, there is no significant uplift of the $\mathrm{SO}_{2}$ over La Réunion and the volcanic plume is still located in the lower troposphere level. From 6 April, due to the very intense volcanic activity, the volcanic plumes cross the trade winds layer, reach the mid-troposphere and spread toward the east (Sect. 5). Indeed, on 6 April, the CALIOP sensor detected three aerosol plumes close to La Réunion at $5500 \mathrm{~m}$ a.s.1, $6500 \mathrm{~m}$ a.s.l. and $7500 \mathrm{~m}$ a.s.1. On 7 April, two aerosol plumes are also observed. The LIDAR provides transects at $800 \mathrm{~km}$ (5500 ma.s.1.) and $1800 \mathrm{~km}$ (7300 ma.s.l.) east of La Réunion. These plumes probably correspond to those observed by OMI on 6 April. $\mathrm{SO}_{2}$ and sulfate aerosol lifetimes are longer in the upper troposphere compared to the lower atmosphere (Stevenson et al., 2003; Yang et al., 2009). Then we assume that the plumes observed by OMI on 6 and 7 April are also those observed by CALIOP at the east on 8, 9, 10 and 11 April, at about 800 and $1100 \mathrm{~km}$ (6500 m a.s.1. and $10200 \mathrm{~m}$ a.s.1.), $1200 \mathrm{~km}$ (6300 ma.s.1.), $1000 \mathrm{~km}$ (9900 ma.s.1.) and $1200 \mathrm{~km}$ (3600 ma.s.1.) from La Réunion, respectively. This is consistent with the shape evolution of $\mathrm{SO}_{2}$ plumes observed with OMI. Plume altitudes in the eastern Indian Ocean suggest that the transport of $\mathrm{SO}_{2}$ continues in the days after the collapse of the crater. The field observations associated with cartography performed using OMI, allow a validation of the higher eastern plumes formed during three days (6, 7 and 8 April). In the western part of the Indian Ocean, between La Réunion and Madagascar, apart from 9 and 11 April (4200 ma.s.1. and $4400 \mathrm{~m}$ a.s.1.), plumes were never observed above $3100 \mathrm{~m}$ a.s.l.. The inversion layer was not crossed by these plumes that were formed by smaller volcanic activity.

\section{Numerical simulation of the event}

\subsection{The MesoNH model}

The mesoscale, non hydrostatic atmospheric model, MesoNH is used in this study. This model has been jointly developed by the Centre National de la Recherche Météorologique and the Laboratoire d'Aérologie (Lafore et al., 1998). MesoNH can be used to simulate small scale (Large Eddy Simulation type) to synoptic scale phenomena (horizontal resolution ranging from a few meters to several tens of kilometers), and it can be run in a two-way nested

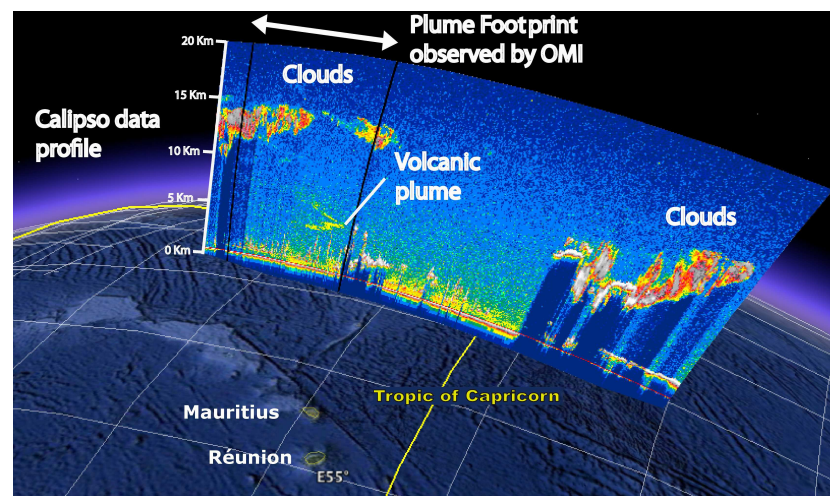

Fig. 4. Vertical CALIOP profile $(532 \mathrm{~nm}$ Total Attenuated Backscattered) over Indian Ocean showing the volcanic Plume on 8 April 2007 at 21:00 UTC (data obtained and modified from http: //www-calipso.larc.nasa.gov/products and Google Earth).

mode involving up to eight nesting stages. Different sets of parameterizations have been introduced for convection (Bechtold et al., 2001), cloud microphysics (Cohard and Pinty, 2000), turbulence (Bougeault and Lacarrere, 1989), gaseous chemistry (Suhre et al., 1998; Tulet et al., 2003) and aerosols (Tulet et al., 2005; Grini et al., 2006).

For this study, the ReLACS chemical scheme (Crassier et al., 2000) has been used to represent the sulfur dioxide $\left(\mathrm{SO}_{2}\right)$ oxidation and the formation of sulfuric acid $\left(\mathrm{H}_{2} \mathrm{SO}_{4}\right)$.

\subsection{Simulation configuration}

The simulation started at 00:00 UTC on 4 April 2007, and ended at 00:00 UTC on 11 April 2007. The simulation domain is the same as the one used for the OMI in Sect. 3.1 $\left(28.6^{\circ} \mathrm{S}\right.$ and $10.9^{\circ} \mathrm{S}$ and $40.78^{\circ} \mathrm{E}$ and $\left.71.22^{\circ} \mathrm{E}\right)$. The horizontal resolution of the model is $20 \mathrm{~km}$ which is comparable to the OMI footprint size $\left(13 \times 24 \mathrm{~km}^{2}\right)$. The vertical grid is composed of 60 vertical levels stretched up to an altitude of $24000 \mathrm{~m}$ a.s.l., with 30 levels between the surface and $1500 \mathrm{~m}$ a.s.l.. The initial and lateral boundary conditions are extracted from ECMWF analysis for the meteorology and from MOCAGE (Peuch et al., 1999) for gas chemistry.

\subsection{Estimation of the day by day $\mathrm{SO}_{2}$ release}

The estimation of the gas emissions in the atmosphere during this eruption is challenging due to the absence of any local rapid observing system of the gas in the vicinity of the volcano. To counterbalance this problem a top-down approach is adopted. Eckhardt et al. (2008) have developed a numerical top-down method to estimate the $\mathrm{SO}_{2}$ vertical profile by a volcanic eruption using satellite column measurement and inverse transport modeling. Although this method is robust and well adapted to the volcanic plume forecasting, we have chosen another way which is more basic, but more adapted to the particular situation of April 2007. Indeed, the strong 
Table 1. Evolution of the column size and the $\mathrm{SO}_{2}$ concentration introduced into the model over La Réunion between 4 April and 10 April, 2007.

\begin{tabular}{lccccccccc}
\hline Day of April, 2007 & 4 & 5 & 5 & 6 & 6 & 7 & 8 & 9 & 10 \\
\hline Hours (UTC) & 11 & 11 & 22 & 9 & 15 & 5 & 11 & 10 & 11 \\
Bottom (m a.s.1.) & surface & 500 & 3500 & 4000 & 4000 & 3000 & 500 & surface & surface \\
Top (m a.s.l.) & 2000 & 5000 & 6000 & 9000 & 9000 & 8000 & 4000 & 2500 & 2500 \\
$\mathrm{SO}_{2}$ (Du) & 3 & 30 & 70 & 100 & 100 & 40 & 4.5 & 3 & 3 \\
\hline
\end{tabular}

variability in the lava flow between 5 April and 7 April, have engendered strong variability of $\mathrm{SO}_{2}$ concentration in the plume. Moreover this discontinuity in the plume of $\mathrm{SO}_{2}$ (Fig. 2) was reinforced by meteorological processes such as scavenging and chemical transformation of $\mathrm{SO}_{2}$. For these reasons the method used here to determine the $\mathrm{SO}_{2}$ profile above the eruption is based on an analysis of data, simulations, and the knowledge of the phenomenology of the eruption observed on the field. We proceed as follows:

- For each day, except 6 April, the $\mathrm{SO}_{2}$ mass burden characteristics of the area around La Réunion are extracted from OMI. Due to the presence of clouds and the model resolution, the main difficulty is to estimate a characteristic mean value of $\mathrm{SO}_{2}$ suitable to be introduced into the model grid. Then, the estimated $\mathrm{SO}_{2}$ mass burden is converted into a homogeneous concentration of $\mathrm{SO}_{2}$ within the column of atmosphere located above the eruption (Table 1).

The top altitude of this column is estimated following two steps. First, the CALIPSO observations gives an estimate of the aerosol plume maximum altitude (Sect. 3.2). Second, a set of simulations is performed. Since the atmosphere is strongly vertically sheared in these regions (Baray et al., 1998; Clain et al., 2009) (Sect. 5), the lower and upper boundaries of the $\mathrm{SO}_{2}$ column over La Réunion is deduced.

- On 6 April, the lava flux (and the $\mathrm{SO}_{2}$ release) is too variable to use the daily value from satellite. Moreover, as explained before, the presence of clouds prevents a correct estimate of $\mathrm{SO}_{2}$ by OMI over La Réunion. For these reasons, the $\mathrm{SO}_{2}$ concentration introduced in the La Réunion column for 6 April, is estimated through a set of simulations, in order to fit to the plume observed on 7 April. The global daily mass emitted in the simulation is adjusted to the total mass burden observed by OMI on 7 April (see Sect. 6). The evolution of seismicity (Michon et al., 2007), associated with field observations, is also used to estimate the temporal variations of the emissions.

Furthermore, during the major eruptive period the $\mathrm{SO}_{2}$ plume is uplifted by different mechanisms. Convection is forced by the sensible heat flux (lava surface temperature $\sim 1200^{\circ} \mathrm{C}$ ) and the considerable latent heat flux generated by water evaporation when lava entered the ocean. In addition, orographic lifting due to the presence of steep relief (summit at $3070 \mathrm{~m}$ ) can modify the trade winds flux around La Réunion (Lesouef et al., 2008), and can amplify the convection. These two processes are not reproduced by the model due to the horizontal resolution used in this study $(20 \mathrm{~km})$. The orography is smoothed, and the summit of La Réunion in the simulation is lowered to $500 \mathrm{~m}$. For these reasons, the bottom of the $\mathrm{SO}_{2}$ column is chosen above the surface. Several simulations (not shown) have permitted us to adjust the altitude boundaries of the $\mathrm{SO}_{2}$ column introduced into the model. All data introduced into the model are reported in Table 1. At each time step of the model, a linear temporal interpolation is made between all the data of Table 1 .

\section{Evolution of the $\mathrm{SO}_{2}$ plume over the Indian Ocean}

\section{$5.1 \mathrm{SO}_{2}$ mass burden}

Figure 5 represents the evolution of the $\mathrm{SO}_{2}$ mass burden simulated by MesoNH. This figure has to be compared to OMI observations (Fig. 2). The first period of 4 and 5 April shows that the plume is oriented toward the west in agreement with satellite observations. On 5 April, the $\mathrm{SO}_{2}$ mass burden reaches $40 \mathrm{DU}$ over La Réunion, which is the same order of magnitude as OMI observations.

On 6 April, the model is able to reproduce the western and eastern branches of the $\mathrm{SO}_{2}$ plume, but the northern branch observed by OMI north of Mauritius is not wide enough in the simulation. The plume extending from La Réunion to Mauritius presents strong values of $\mathrm{SO}_{2}$ up to $70 \mathrm{DU}$. On 7 April, the model matches the satellite observations. As for OMI observations, the western plume has reached Madagascar (Fig. 2d). The main plume (50 DU) is oriented to the north, then turns to the east at $17^{\circ} \mathrm{S}$. A large maximum at $40 \mathrm{DU}$ is simulated north of Mauritius, which corresponds to the maximum of emission that occurred on 6 April. As in the observations, the simulated $\mathrm{SO}_{2}$ plume reaches the eastern boundary of the domain. On 8 and 9 April, the $\mathrm{SO}_{2}$ emission decreases strongly and the $\mathrm{SO}_{2}$ mass burden is moderate over La Réunion (4 to $10 \mathrm{DU}$ ). During this latter period, the simulation shows that the strong $\mathrm{SO}_{2}$ mass burden modeled on 6 and 7 April have been transported toward the south of 

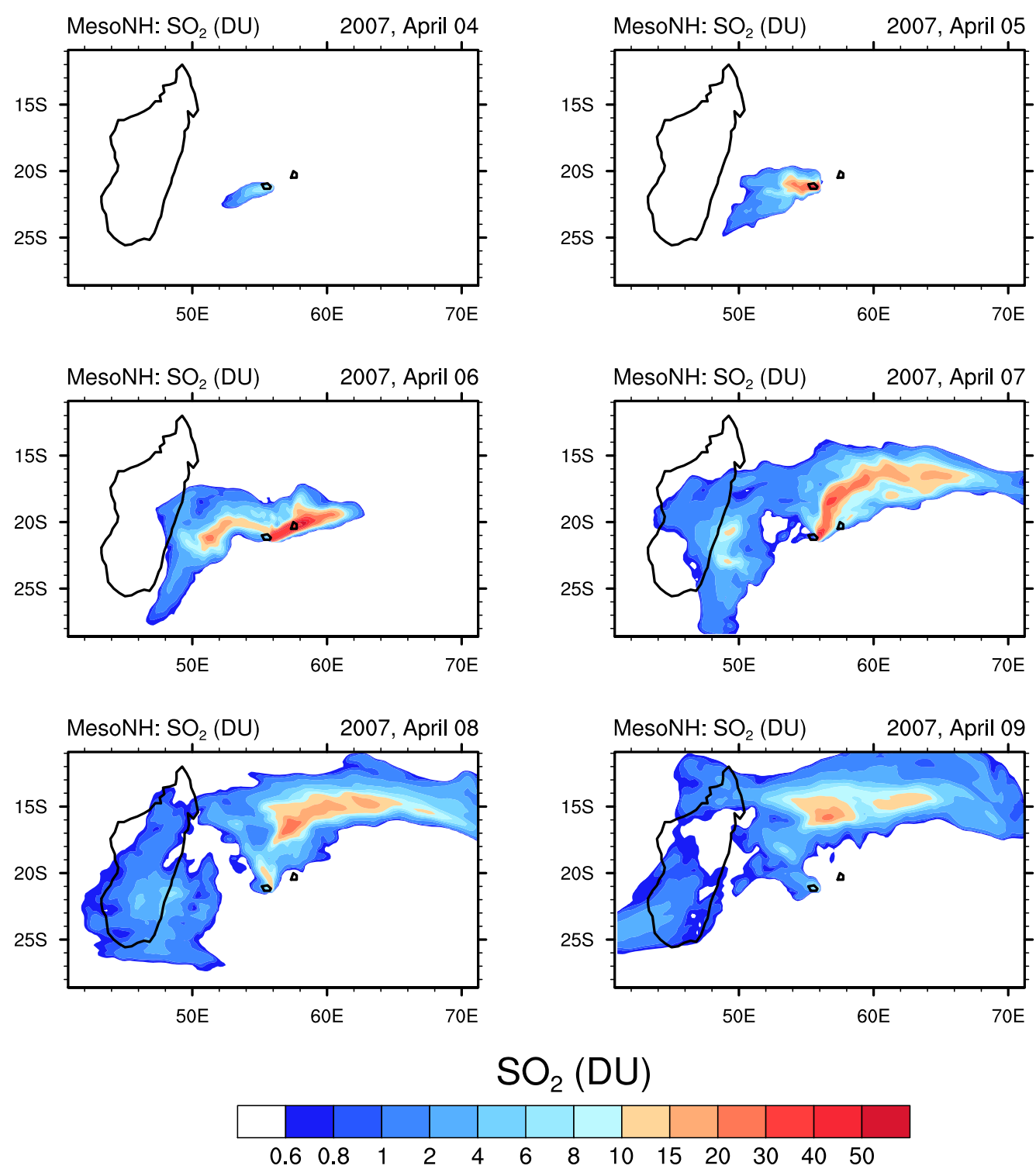

Fig. 5. Evolution of $\mathrm{SO}_{2}$ mass burden simulated by MesoNH at 12:00 UTC for the period 4-9 April 2007.

Madagascar and to the north-east of the domain. An intense tongue, with a maximum of $20 \mathrm{DU}$, extends over more than $1500 \mathrm{~km}$ on 8 April.

\subsection{April, vertical $\mathrm{SO}_{2}$ distribution}

To detail the vertical distribution of the $\mathrm{SO}_{2}$ plume, Fig. 6 displays the $\mathrm{SO}_{2}$ concentration and the horizontal wind field at different altitudes on 7 April 2007 at 12:00 UTC. Close to the surface, the trade winds $\left(6 \mathrm{~m} \mathrm{~s}^{-1}\right.$ above La Réunion) turns the $\mathrm{SO}_{2}$ plume towards the west of La Réunion. The modeled surface $\mathrm{SO}_{2}$ concentration is low. Our definition of the bottom altitude of the $\mathrm{SO}_{2}$ column (Table 1) limits the plume extension to the west, as in OMI observations. Close to the eastern coast of Madagascar, the plume is more intense (20-40 ppbv) corresponding to the westerly plume of 5 April.

Due to the vertical wind shear over La Réunion, the plume is oriented to the north-west between 2 and $3 \mathrm{~km}$ a.s.l., to the north at $4 \mathrm{~km}$ a.s.l. and to the north-east at $6 \mathrm{~km}$ a.s.l. (Fig. 5). As a consequence, the location of the $\mathrm{SO}_{2}$ concentration maxima depends on the altitude. At $4 \mathrm{~km}$ asl, the maximum $\mathrm{SO}_{2}$ mixing ratio (100 ppbv) is located north of La Réunion. At $6 \mathrm{~km}$ a.s.l., the plume is strengthened with a maximum mixing ratio of more than 500 ppbv.

In the upper part of the plume (between 6 and $8 \mathrm{~km}$ a.s.l.), the plume is advected to a large distance from La Réunion by the south-west wind $\left(10-15 \mathrm{~m} \mathrm{~s}^{-1}\right)$. At $8 \mathrm{~km}$ a.s.l., the $\mathrm{SO}_{2}$ maximum mixing ratio decreases to $100 \mathrm{ppbv}$. 

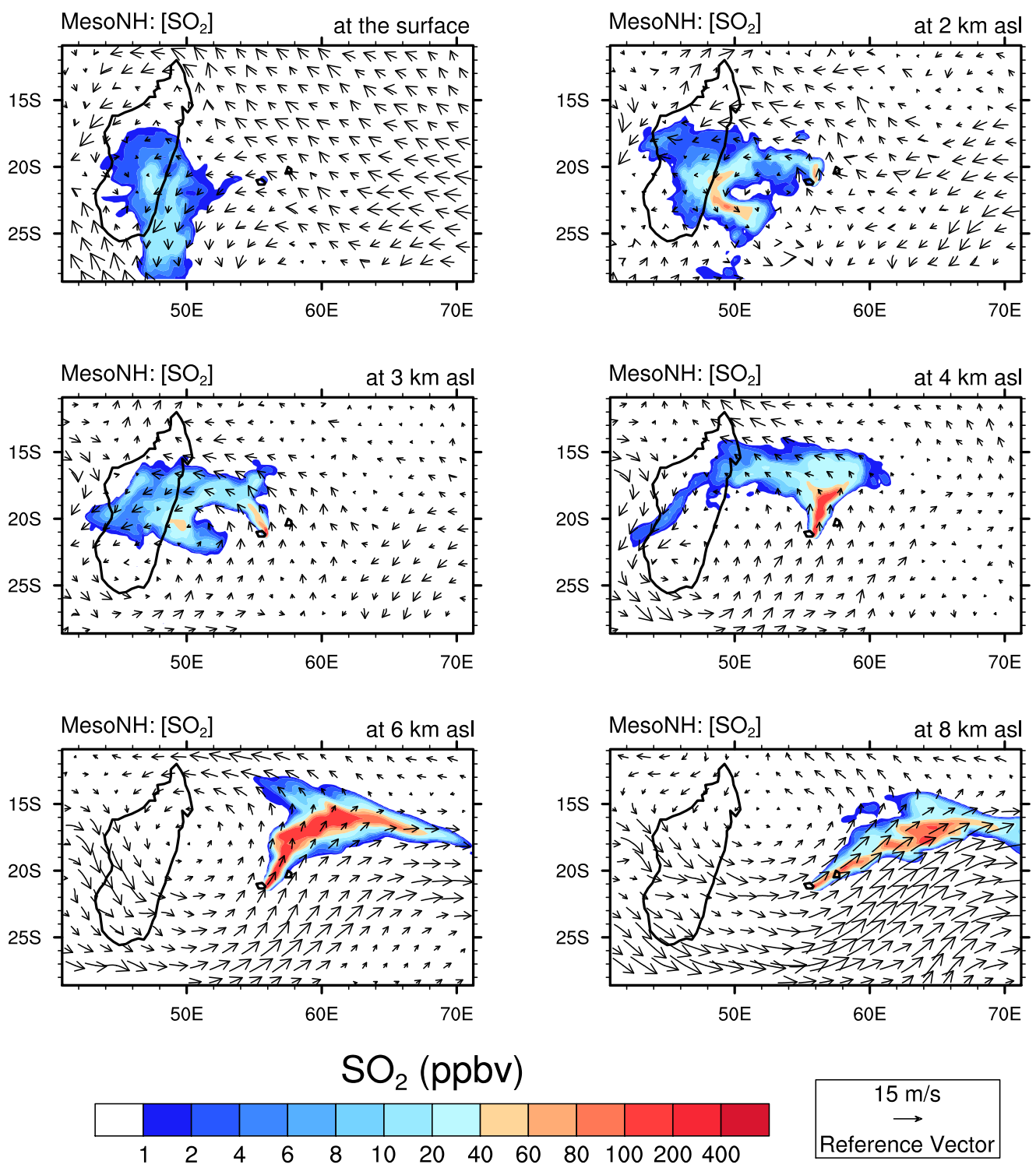

Fig. 6. Mixing ratio of $\mathrm{SO}_{2}$ (ppbv) and horizontal wind vector (reference at the bottom right) simulated by MesonH on 7 April 2007 , at different levels (surface, $2 \mathrm{~km}$ a.s.1., $3 \mathrm{~km}$ a.s.1., $4 \mathrm{~km}$ a.s.1., $6 \mathrm{~km}$ a.s.1. and $8 \mathrm{~km}$ a.s.1.).

As for this particular day, the synoptic winds regime remains strongly sheared on the vertical during all the studied period. As explained in Sect. 4.2, a comparison between the plume observed by OMI and that given by different simulations, is used to initialize the altitude of the $\mathrm{SO}_{2}$ plume above La Reunion.

\subsection{Acid formation and deposition}

This section is dedicated to an overview of the $\mathrm{SO}_{2}$ and $\mathrm{H}_{2} \mathrm{SO}_{4}$ dry deposition. Figure 7 shows the temporal integration of the $\mathrm{SO}_{2}$ and $\mathrm{H}_{2} \mathrm{SO}_{4}$ mass deposited on the surface between 4 April and 10 April. Dry deposition occurs on the western part of the domain. Indeed, only this area is concerned by the significant surface concentration of $\mathrm{SO}_{2}$ that is advected by the trade winds. In the simulation, about $25 \mathrm{mgS} \mathrm{m}^{-2}$ (miligrams of sulfur per cubic meter) of $\mathrm{SO}_{2}$ is deposited in the vicinity of La Réunion, and $5-20 \mathrm{mgS} \mathrm{m}^{-2}$ in a large tongue south east of Madagascar (Fig. 7a). The order of magnitude of $\mathrm{SO}_{2}$ mass deposition on land over Madagascar is in the range $0.2-4 \mathrm{mgS} \mathrm{m}^{-2}$.

For $\mathrm{H}_{2} \mathrm{SO}_{4}$ (Fig. 7b), the location of the mass deposition is quite different from $\mathrm{SO}_{2}$. Indeed, $\mathrm{H}_{2} \mathrm{SO}_{4}$, as a secondary species, is formed within the plume. As a consequence, the surface concentration of $\mathrm{H}_{2} \mathrm{SO}_{4}$ is located in the western part of the domain (not shown), and a maximum of $7 \mathrm{mgS} \mathrm{m}^{-2}$ of sulfuric acid deposit is simulated over the south-east of Madagascar. The total dry deposition over the simulation 


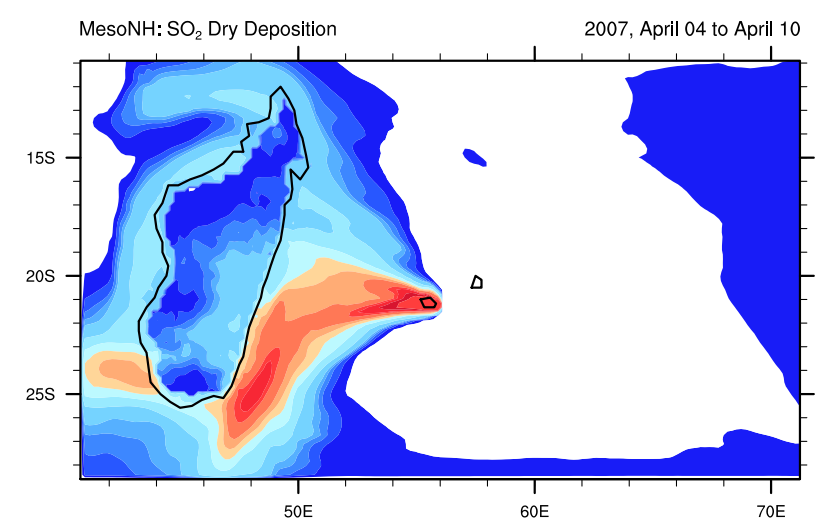

$\mathrm{SO}_{2}$ Dry Deposition (mgS m $\mathrm{m}^{-2}$ )

a)

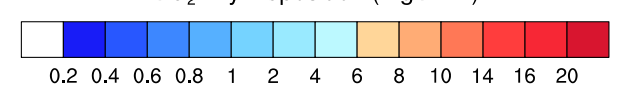

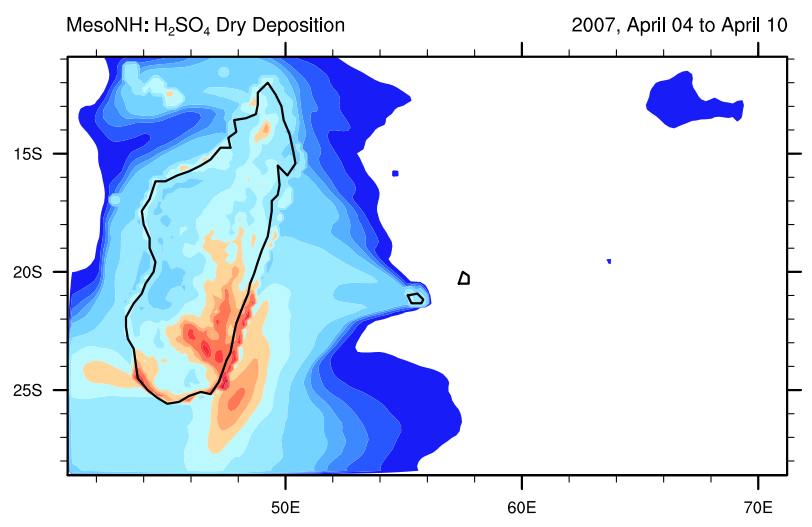

$\mathrm{H}_{2} \mathrm{SO}_{4}$ Dry Deposition (mgS m²)

b)

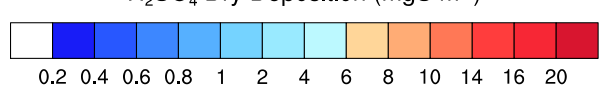

Fig. 7. Surface dry deposition of $\mathrm{SO}_{2}$ (a) and $\mathrm{H}_{2} \mathrm{SO}_{4}(\mathbf{b})\left(\mathrm{mgS} \mathrm{m}^{-2}\right)$, simulated by MesoNH between 4 April and 11 April 2007.

domain for $\mathrm{SO}_{2}$ and $\mathrm{H}_{2} \mathrm{SO}_{4}$ is estimated to $27 \mathrm{kt}(13.5 \mathrm{kt}$ of sulfur) and $21 \mathrm{kt}$ ( $6.8 \mathrm{kt}$ of sulfur), respectively.

\section{Mass budget and estimated flux}

\subsection{Mass budget}

This last section is devoted to the estimation of the mass budget of sulfur released into the atmosphere. Figure 8 shows the evolution of the integrated mass over the simulation domain for OMI (triangles, squares and circles), and for the simulation (solid lines). A volume calculation is performed on each "Digital $\mathrm{SO}_{2}$ Model" with a threshold at 0.7 DU for TRL and 0.3 DU for TRM (Sect. 3.1).

OMI observed a very pronounced evolution of $\mathrm{SO}_{2}$ mass, from 10-20 kt on 5 April, to $140 \mathrm{kt}$ (TRM) and $286 \mathrm{kt}$ (TRL) on 7 April. One major problem comes from the strong deviation between TRM and TRL. To improve the OMI mass estimation, we assume that the center mass of the plume is located at $6000 \mathrm{~m}$ a.s.l. after the 6 April. This altitude corresponds to the center of the $\mathrm{SO}_{2}$ plume estimated above $\mathrm{La}$ Reunion, during the period of maximum degassing (see Table 1). The estimated OMI value, weighted between TRL and TRM, is represented on Fig. 8 by squares. With this assumption, we estimate the maximum $\mathrm{SO}_{2}$ mass at $190 \mathrm{kt}$ on 7 April. After 7 April, the $\mathrm{SO}_{2}$ mass decreases strongly and reaches $100 \mathrm{kt}$ ( $68 \mathrm{kt}$ for TRM and $155 \mathrm{kt}$ for TRL) on 8 April. Then, the $\mathrm{SO}_{2}$ mass decreases slowly. On 10 April, the $\mathrm{SO}_{2}$ mass reaches $41 \mathrm{kt}$ (TRM) and $77 \mathrm{kt}$ (TRL).

The black solid line in Figure 8 gives the evolution of an inert gas for which no chemical transformation or deposition can occur. The maximum of this curve reaches $219 \mathrm{kt}$ on 7 April. The decrease in the simulated mass after midday on 7 April corresponds to the mass escape through the domain

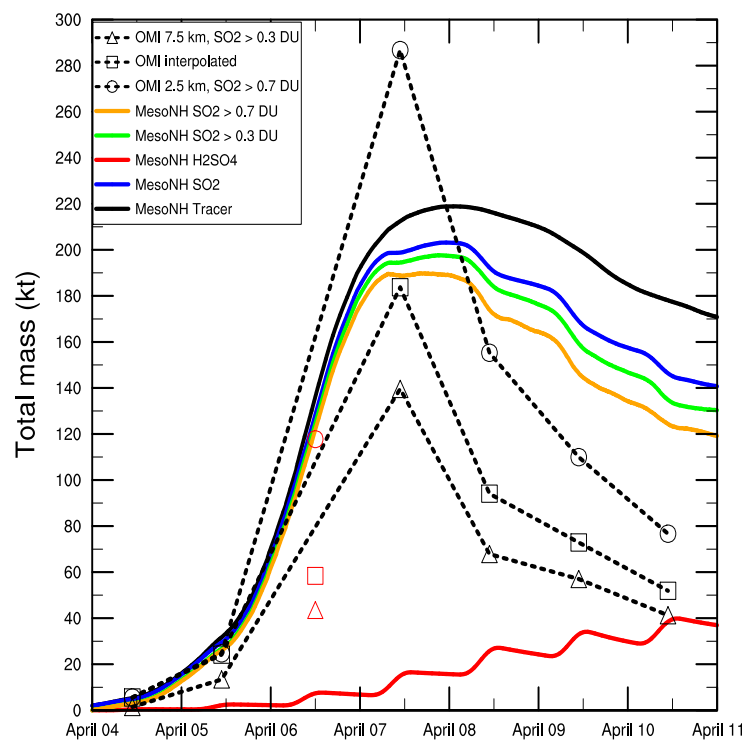

Fig. 8. Sum of the mass (kt) simulated by MesoNH on the whole domain (solid lines) and observed by OMI (dashed lines with triangles, squares and circles) between 4 April and 11 April 2007. Black, blue, green, yellow and red solid lines correspond to the passive tracer, the $\mathrm{SO}_{2}$, the $\mathrm{SO}_{2}$ where the mass burden is higher than $0.3 \mathrm{DU}$, the $\mathrm{SO}_{2}$ where the mass burden mass is higher than 0.7 DU, and the $\mathrm{H}_{2} \mathrm{SO}_{4}$, respectively. Black triangles, circles and squares correspond to the OMI total mass given by TRM, TRL and weighted between TRL and TRM, respectively. Red triangles, circles and squares represent underestimated OMI values.

boundary. It can be estimated $50 \mathrm{kt}$, but cannot explain the $210 \mathrm{kt}$ and $110 \mathrm{kt}$ decrease during the period, observed by OMI upon TRL or TRM, respectively. 


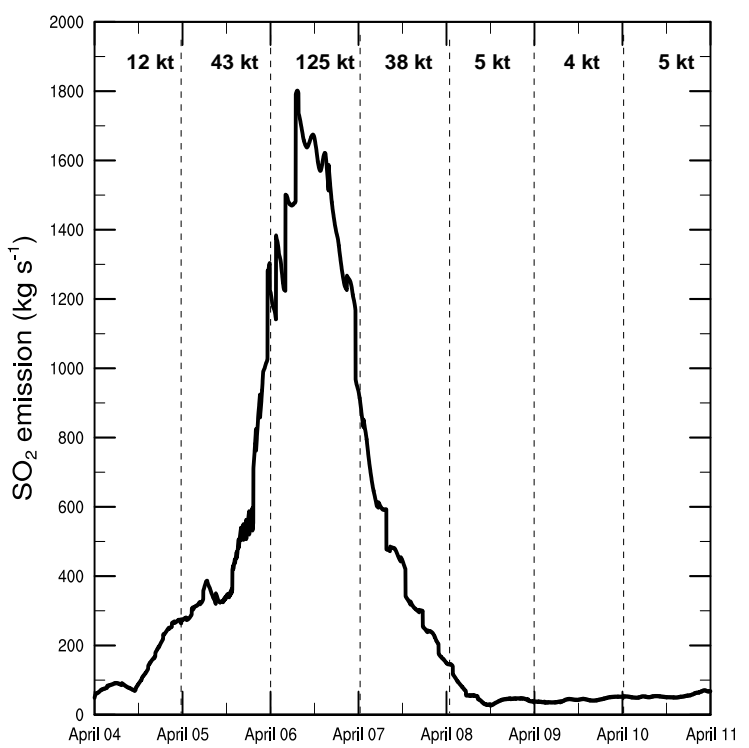

Fig. 9. Evolution of the $\mathrm{SO}_{2}$ emission $\left(\mathrm{kg} \mathrm{s}^{-1}\right)$ estimated by MesoNH between 4 April and 11 April 2007. Values along the top correspond to daily mass of $\mathrm{SO}_{2}(\mathrm{kt})$ emitted during the period.

The evolution of the simulated $\mathrm{SO}_{2}$ mass (solid blue line) differs from the tracer by two integrative processes: the chemical oxidation into $\mathrm{H}_{2} \mathrm{SO}_{4}$ and the dry deposition to the surface. Thus, the evolution of the $\mathrm{SO}_{2}$ mass reaches a maximum at $200 \mathrm{kt}$ on 8 April, and then decreases to $140 \mathrm{kt}$ at the end of the simulation. In parallel, the $\mathrm{H}_{2} \mathrm{SO}_{4}$ (solid red line) gradually increases to $40 \mathrm{kt}$ on 10 April. The oscillation in the production of $\mathrm{H}_{2} \mathrm{SO}_{4}$ corresponds to the balance between the oxidation of $\mathrm{SO}_{2}$, which is efficient during the day, and the loss by dry deposition or the escape through the domain boundaries. Nevertheless, the evolution of the $\mathrm{SO}_{2}$ mass that integrates the loss at the surface, the oxidation and the escape out of the domain still overestimates by at least $60 \mathrm{kt}$ the mass observed by OMI at the end of the simulated period.

To compare with TRM and TRL, two other curves filter out every column of $\mathrm{SO}_{2}$ lower than $0.3 \mathrm{DU}$ (green solid line) and $0.7 \mathrm{DU}$ (yellow solid line). These new curves reproduces the increase of the integrated mass between 4 April and 7 April, and reaches the maximum estimated value of $190 \mathrm{kt}$ on 7 April (Fig. 8). The decrease of mass reaches $120 \mathrm{kt}$ at the end of the simulation, which represents an overestimation ranging between 40 and $80 \mathrm{kt}$ compared to OMI values. Three hypotheses related to the presence of clouds can be given to explain these differences. First, cloud prevents the correct observation of $\mathrm{SO}_{2}$ : in cloudy regions, the mass observed by OMI is underestimated in agreement with Carn et al. (2008). This is clear for 6 April where the weather over La Réunion and Mauritius is cloudy (Fig. 2c). This is also visible through the discontinuity in the observed plume on 7 April (Fig. 2d). Second, the presence of clouds implies the possible presence of precipitation that can scavenge the $\mathrm{SO}_{2}$. Comparing the simulated and the observed $\mathrm{SO}_{2}$ in Madagascar region on 8 and 9 April, (Figs. 2 and 5), we can assume that a non-negligible amount of $\mathrm{SO}_{2}$ is washed out. Third, the model does not integrate the aqueous chemistry that transforms the $\mathrm{SO}_{2}$ into $\mathrm{H}_{2} \mathrm{SO}_{4}$ in cloud droplets. So, in cloudy areas, the formation of $\mathrm{H}_{2} \mathrm{SO}_{4}$ is underestimated by the model which could explain part of the modeled $\mathrm{SO}_{2}$ overestimation during the last period.

In addition the dispersion of $\mathrm{SO}_{2}$ over time will decrease the column amounts below the OMI detection limits, particularly at the fringes of the volcanic plume. So, less $\mathrm{SO}_{2}$ will be measured from space, even though the $\mathrm{SO}_{2}$ is still present. The model does not suffer from this finite sensitivity.

\subsection{Estimation of the $\mathrm{SO}_{2}$ flux}

To estimate the $\mathrm{SO}_{2}$ release into the atmosphere, the $\mathrm{SO}_{2}$ concentration introduced in the model is maintained in the column above Piton de la Fournaise (Sect. 4.3). Then the emission at the surface must compensate for the mass of $\mathrm{SO}_{2}$ advected out of the column located above the eruption. It can be formulated using the initial $F(0)$ and the iterative $F(t)$ fluxes (in $\mu \mathrm{g} \mathrm{m}^{-2} \mathrm{~s}^{-1}$ ) defined as:

$$
F(0)=\frac{M_{\mathrm{SO}_{2}}}{M_{\text {air }} \Delta t} \sum_{k=\text { bot }}^{\text {top }} \rho_{k}\left[\mathrm{SO}_{2}\right]_{k} \Delta Z_{k}
$$

and

$F(t)=$

$\frac{M_{\mathrm{SO}_{2}}}{M_{\mathrm{air}} \Delta X \Delta Y} \sum_{k=\text { bot }}^{\text {top }} \rho_{k}\left[\mathrm{SO}_{2}\right]_{k} \Delta Z_{k}\left(u_{k} \Delta Y+v_{k} \Delta X-u_{k} v_{k} \Delta t\right)$

where $\left[\mathrm{SO}_{2}\right]_{k}$ is the $\mathrm{SO}_{2}$ concentration at level $k$ (ppbv), $\Delta t$ the time step of the model (s), $\rho_{k}$ the air density $\left(\mathrm{kg} \mathrm{m}^{-3}\right), u_{k}$ and $v_{k}$ the zonal and meridian wind $\left(\mathrm{m} \mathrm{s}^{-1}\right)$, and $\Delta X, \Delta Y$, $\Delta Z_{k}$ the grid sizes of the domain along the west-east and south-north axes, and the altitude $(\mathrm{m})$. The index $k$ represents the altitude level of the model. $M_{\mathrm{SO}_{2}}$ and $M_{\text {air }}\left(\mathrm{kg} \mathrm{mol}^{-1}\right)$ represent the molecular weight for $\mathrm{SO}_{2}$ and air, respectively.

Using this formulation, the $\mathrm{SO}_{2}$ emission estimated by the model is shown in Fig. 9. The model retrieves a strong evolution of the emission on 6 April reaching $1800 \mathrm{~kg} \mathrm{~s}^{-1}$ over a surface of $20 \times 20 \mathrm{~km}^{2}$ which corresponds to the surface of the horizontal grid of the model. This strong increase is related to the increase of $\mathrm{SO}_{2}$ concentration introduced into the eruptive column on 6 April (Table 1). Note that this evolution of the emission is not smoothed due to the variability of the horizontal wind. A day by day mass budget is also reported in Fig. 9. The analytic computation of the mass emission during the main days of the eruption is $12 \mathrm{kt}, 43 \mathrm{kt}$ and $125 \mathrm{kt}$ for 5 April, 6 April and 7 April, respectively. The total emission given by the model during the period is $231 \mathrm{kt}$ of $\mathrm{SO}_{2}$, and $218 \mathrm{kt}$ until 8 April. This latter value is comparable to the 
maximum mass of the tracer simulated ( $219 \mathrm{kt})$. These computations integrate many sources of possible errors from the model (winds and depositions), and from the $\mathrm{SO}_{2}$ mass retrieved by OMI (algorithm, altitude of the plume on 7 April). Then, these estimations must be taken with caution and as an order of magnitude.

\section{Conclusions}

This original study has two objectives. Firstly, it is devoted to analysis at the synoptic scale of the evolution of $\mathrm{SO}_{2}$ released into the atmosphere by the eruption of the Piton de la Fournaise volcano. OMI observations show a strong variability in the mass of $\mathrm{SO}_{2}$ over the domain. The first question is to understand which physical processes are able to generate this strong variability. The simulation of the event using the mesoscale model MesoNH gave some answers. Several numerical three-dimensional calibration runs of the model were performed using the OMI and CALIPSO observations, and through the comparison of the large scale plumes provided by MesoNH and OMI. The final result gives a correct representation of the main plumes by the model during the period 4-9 April 2007. The model estimates that $231 \mathrm{kt}$ of $\mathrm{SO}_{2}$ is emitted by the volcano into the atmosphere during the period. During this event, the simulation estimates that within the domain, $60 \mathrm{kt}$ of $\mathrm{SO}_{2}$ are oxidized into $\mathrm{H}_{2} \mathrm{SO}_{4}$, of which $21 \mathrm{kt}$ are lost at the surface by dry deposition. A sink of $27 \mathrm{kt}$ of $\mathrm{SO}_{2}$ by dry deposition must be added to the $\mathrm{SO}_{2}$ budget. By differencing with the total amount of $\mathrm{SO}_{2}$ present in the atmosphere at the end of the simulation ( $140 \mathrm{kt})$, less than $4 \mathrm{kt}$ of $\mathrm{SO}_{2}$ are estimated to have escaped through the domain boundaries.

Nevertheless, these mass budgets have to be taken with caution. Due to the resolution of the model, it cannot correctly represents the cloud microphysics, the aqueous process of scavenging by rain and the $\mathrm{SO}_{2}$ transformation into acid in the cloud droplets are not taken into account in this study. As a consequence, the total deposition at the surface and the amount of acid formed is underestimated. Thus, the estimation of the $\mathrm{SO}_{2}$ released into the atmosphere on 6 April, where precipitations are present, is also probably underestimated. For these reasons, the values of $\mathrm{SO}_{2}$ mass and the chemical transformation given by the model have to be taken as a low limit of the reality.

The second objective of this study is to retrieve the $\mathrm{SO}_{2}$ emission during the eruption by a top-down approach. It consists of maintaining an $\mathrm{SO}_{2}$ concentration in a column located above Piton de la Fournaise. The estimation of the $\mathrm{SO}_{2}$ surface flux is then based on the fact that the emission flux is equal to the export of $\mathrm{SO}_{2}$ out of the eruptive column. Using this method a strong variability of $\mathrm{SO}_{2}$ emission is retrieved, in particular with a peak on 6 April reaching $1800 \mathrm{~kg} \mathrm{~s}^{-1}$ on the surface model grid.
One important perspective of this study is to introduce this surface flux estimate into high resolution simulations. Through high resolution studies, it will be possible to reproduce the local convection, the precipitation and the aqueous chemical transformation of gas that formed acid rains. These topics that link the air pollution and their consequences on human health and ecosystems will constitute the future plans for this work.

Acknowledgements. We greatly acknowledge F. Caillé and R. Delmas for providing the pictures of the 2007 eruption. We thank L. Michon and N. Krotkov for their relevant comments. We also would like to thank the MesoNH assistance team for their support, the KNMI OMI team and the NASA Goddard Earth Sciences Data and Information Services Center for producing L2 OMI SO2 and the NASA CALIPSO team for the online free access CALIPSO archives. Lastly, we are grateful to C. Barthe, J. Kemp and J. G. Murphy for improvement of the English.

Edited by: J. G. Murphy

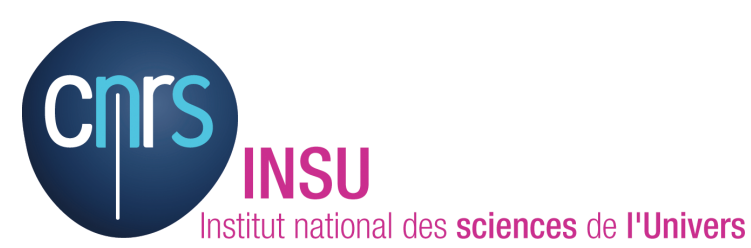

The publication of this article is financed by CNRS-INSU.

\section{References}

Afe, O., Richter, A., Sierk, B., Wittrock, F., and Burrows, J.: BrO Emission from Volcanoes - a Survey using GOME and SCIAMACHY Measurements, Geophys. Res. Lett., 31, 124113, doi:10.1029/2004GL020994, 2004.

Arellano, S., Hall, M., Samaniego, P., LePennec, J., Ruiz, A., Molina, I., and Yepes, H.: Degassing patterns of Tungurahua volcano (Ecuador) during the 1999-2006 eruptive period, inferred from remote spectroscopic measurements of $\mathrm{SO}_{2}$ emissions, J. Volcanol. Geotherm. Res., 176, 151-162, doi:10.1016/j.jvolgeores.2008.07.007, 2008.

Baray, J., Ancellet, G., Taupin, F., Bessafi, M., Baldy, S., and Keckhut, P.: Subtropical tropopause break as a possible stratospheric source of ozone in the tropical troposphere, J. Atmos. Sol.-Terr. Phys., 60, 27-36, 1998.

Bechtold, P., Bazile, E., Guichard, F., Mascart, P., and Richard, E.: A mass-flux convection scheme for regional and global models, Q. J. Roy. Meteorol. Soc., 127, 869-886, 2001.

Bhugwant, C., Siéja, B., Bessafi, M., Staudacher, T., and Ecormier, J.: Atmospheric sulfur dioxide measurements during the 2005 and 2007 eruptions of the Piton de la Fournaise volcano: Implications for human health and environmental changes, J. Volcanol. Geotherm. Res., 184, 208-224, doi:10.1016/j.jvolgeores.2009.04.012, 2008.

Bougeault, P. and Lacarrere, P.: Parametrization of orographyinduced turbulence in a meso-beta model, Mon. Weather Rev., 117, 1872-1890, 1989. 
Carn, S. A., Krotkov, N. A., Yang, K., Hoff, R. M., Prata, A. J., Krueger, A. J., Loughlin, S. C., and Levelt, P. F.: Extended observations of volcanic SO2 and sulfate aerosol in the stratosphere, Atmos. Chem. Phys. Discuss., 7, 2857-2871, doi:10.5194/acpd7-2857-2007, 2007.

Carn, S. A., Krueger, A., Arellano, S., Krotkov, N., and Yang, K.: Daily monitoring of Ecuadorian volcanic degassing from space, J. Volcanol. Geotherm. Res., 176, 141-150, doi:10.1016/j.jvolgeores.2008.01.029, 2008.

Clain, G., Baray, J. L., Delmas, R., Diab, R., Leclair de Bellevue, J., Keckhut, P., Posny, F., Metzger, J. M., and Cammas, J. P.: Tropospheric ozone climatology at two Southern Hemisphere tropical/subtropical sites, (Reunion Island and Irene, South Africa) from ozonesondes, LIDAR, and in situ aircraft measurements, Atmos. Chem. Phys., 9, 1723-1734, doi:10.5194/acp-9-17232009, 2009.

Cohard, J. and Pinty, J.: A comprehensive two-moment warm microphysical bulk scheme, II: 2D experiments with a non hysrostatic model, Q. J. Roy. Meteorol. Soc., 126, 1843-1859, 2000.

Coppola, D., Piscopo, D., Staudacher, T., and Cigolini, C.: Lava discharge rate and effusive pattern at Piton de la Fournaise from MODIS data, J. Volcanol. Geotherm. Res., 184, 174-192, doi:10.1016/j.jvolgeores.2008.11.031, 2009.

Crassier, V., Suhre, K., Tulet, P., and Rosset, R.: Development of a reduced chemical scheme for use in mesoscale meteorological models, Atmos. Environ., 34, 2633-2644, 2000.

Delmelle, P., Stix, J., Baxter, P., Garcia-Alvarez, J., and Barquero, J.: Atmospheric dispersion, environmental effects and potential health hazard associated with the low-altitude gas plume of Masaya volcano, Nicaragua, Earth Environ. Sci, 423-434, doi:10.1007/s00445-002-0221-6, 2002.

Deroussi, S., Diament, M., Feret, J., Nebut, T., and Staudacher, T.: Localization of cavities in a thick lava flow by microgravimetry, J. Volcanol. Geotherm. Res., 184, 193-198, doi:10.1016/j.jvolgeores.2008.10.002, 2009.

Diab, R., Thompson, A., Mari, K., Ramsay, L., and Coetzee, G.: Tropospheric ozone climatology over Irene, South Africa, From 1990 to 1994 and 1998 to 2002, J. Geophys. Res., 109, D20301, doi:10.1029/2004JD004793, 2004.

Eckhardt, S., Prata, A. J., Seibert, P., Stebel, K., and Stohl, A.: Estimation of the vertical profile of sulfur dioxide injection into the atmosphere by a volcanic eruption using satellite column measurements and inverse transport modeling, Atmos. Chem. Phys., 8, 3881-3897, doi:10.5194/acp-8-3881-2008, 2008.

Edmonds, M., Oppenheimer, C., Pyle, D., and Herd, R.: Rainwater and ash leachate analysis as proxies for plume chemistry at Soufrière Hills Volcano, Monserrat, in: Volcanic Degassing, edited by: Oppenheimer, C. D. P. and Barclay, J., 213, 203-218, Geophysical Society, London Special Publication, 2003.

Georgoulias, A., Balis, D., Koukouli, M., Meleti, C., Bais, A., and Zerefos, C.: A study of the total atmospheric sulfur dioxide load using ground-based measurements and the satellite derived Sulfur Dioxide Index, Atmos. Environ., 43(9), 1693-1701, doi:10.1016/j.atmosenv.2008.12.012, 2009.

Grini, A., Tulet, P., and Gomes, L.: Dusty weather forecast using the MesoNH atmospheric model, J. Geophys. Res., 111, D19205, doi:10.1029/2005JD007007, 2006.

Hoffman, D. J.: Perturbations to the global atmosphere associated with the El Chichón volcanic eruption of 1982, Rev. Geophys.,
25, 743-759, 1987.

Hoffman, D. J., Rosen, J., and Gringel, W.: Delayed production of sulfuric acid condensation nuclei in the polar stratosphere from El Chichon volcanic vapors, J. Geophys. Res., 90, 2341-2354, 1985.

Khokhar, M., Frankenberg, C., VanRoozendael, M., Beirle, S., Kuhl, S., Richter, A., Platt, U., and Wagner, T.: Satellite observations of atmospheric SO2 from volcanic eruptions during the time-period of 1996-2002, Adv. Space Res., 36(5), 879-887, 2005.

Krotkov, N., Carn, S., Krueger, A., Bhartia, P., and Yang, K.: Band residual difference algorithm for retrieval of SO2 from the Aura Ozone Monitoring Instrument (OMI), IEEE Trans. Geosci. Remote Sens., 44(5), 1259-1266, 2006

Krotkov, N., McClure, B., Dickerson, R., Carn, S., Li, C., Bhartia, P., Yang, K., Krueger, A., Li, Z., Levelt, P., Chen, H., Wang, P., and $\mathrm{Lu}, \mathrm{D}$.: Validation of SO2 retrievals from the Ozone Monitoring Instrument over NE China, J. Geophys. Res., 113 D16S40, doi:10.1029/2007JD008818, 2008.

Krueger, A., Walter, L., Bhartia, P., Schnetzler, C., Krotkov, N., Sprod, I., and Bluth, G.: Volcanic sulfur dioxide measurements from the total ozone mapping spectrometer instruments, J. Geophys. Res., 100(D7), 14057-14076, 1995.

Kulmala, M., Laaksonen, A., and Pirjola, L.: Parametrization for sulfuric acid/water nucleation rates, J. Geophys. Res., 103(D7), 8301-8307, 1998.

Lafore, J. P., Stein, J., Asencio, N., Bougeault, P., Ducrocq, V., Duron, J., Fischer, C., Héreil, P., Mascart, P., Masson, V., Pinty, J. P., Redelsperger, J. L., Richard, E., and Vilà-Guerau de Arellano, J.: The Meso-NH Atmospheric Simulation System, Part I: adiabatic formulation and control simulations, Ann. Geophys., 16, 90-109, doi:10.1007/s00585-997-0090-6, 1998.

Lenat, J. and Bachelery, P.: Dynamics of Magma Transfer at Piton de La Fournaise Volcano (Réunion Island, Indian Ocean), in: Earth Evolution Sciences - Special Issue Modeling of Volcanic Processes, edited by: Chi-Yu, K. and Scarpa, R., 57-72, Friedr. Vieweg and Sohn, Brauschweig/Wiesbaden, 1987.

Lesouef, D., Gheusi, F., and Delmas, R.: Etude numérique des circulations locales à la Réunion: application aux transports de polluants, La Météorologie, 62, 32-38, 2008.

Martin, R., Mather, T., Pyle, D., Power, M., Allen, A., Aiuppa, A., Horwell, C., and Ward, E.: Composition-resolved size distributions of volcanic aerosols in the Mt. Etna plumes, J. Geophys. Res., 113, D17211, doi:10.1029/2007JD009648, 2008.

Mather, T., Pyle, D., and Oppenheimer, C.: Tropospheric Volcanic Aerosol, Geophys. Mono., 139, 189-212, doi:10.1029/139GM12, 2005.

McCormick, M., Thomason, L., and Trepte, C.: Atmospheric effects of the Mt-Pinatubo eruption, Nature, 373, 399-404, 1995.

Michon, L., Staudacher, T., Ferrazzini, V., Bachelery, P., and Marti, J.: April 2007 collapse of Piton de la Fournaise: a new example of caldera formation, Geophys. Res. Lett., 31, 121301, doi:10.1029/2007GL031248, 2007.

Michon, L., Villeneuve, N., Catry, T., and Merle, O.: How summit calderas collapse on basaltic volcanoes: New insights from the April 2007 caldera collapse of Piton de la Fournaise volcano, J. Volcanol. Geotherm. Res., 184, 138-151, doi:10.1016/j.jvolgeores.2008.11.003, 2009.

Oppenheimer, C., Pyle, D., and Barclay, J.: Volcanic degassing, 
Geophysical Society, London Special Publication, 213, 2003.

Peltier, A., Staudacher, T., Bachelery, P., and Cayol, V.: Formation of the April 2007 caldera collapse at Piton de La Fournaise volcano: Insights from GPS data, Volcanol. Geotherm. Res., 184, 152-163, doi:10.1016/j.jvolgeores.2008.09.009, 2009.

Penner, J., Andreae, M., Annegarn, H., Barrie, L., Feichter, J., Hegg, D., Jayaraman, A., Leaitch, R., Murphy, D., Nganga, J., and Pitari, G.: Aerosols, their direct and indirect effects, in: Climate Change: The scientific basis, edited by: Houghton, J. T., Ding, Y., Griggs, D. J., Noguer, M., Van der Linden, P. J., Dai, X., Maskell, K., and Johnson, C. A., Cambridge University Press, UK, 289-349, 2001.

Peuch, V., Amodei, M., Barthet, T., Cathala, M., Josse, B., Michou, M., and Simon, P.: MOCAGE : Modéle de Chimie Atmosphérique á Grande Echelle, AMA, CNRM, Toulouse, France, 1999.

Pollack, J., Toon, O., Danielsen, E., Hofmann, D., and Rosen, J.: The El Chichón volcanic cloud - an introduction, Geophys. Res. Lett., 10, 989-992, 1983.

Robock, A.: Pinatubo eruption - The climatic aftermath, Science, 295, 1242-1244, 2002.

Saint-Ange, S.: La sédimentation volcanoclastique en contexte de point chaud (ile de La Rénion, Océan Indien), Thesis, University of La Reunion, France, 2009.

Seifert, P., Gross, S., Ansmann, A., Freudenthaler, V., Hiebsch, A., Schmidt, J., Schnell, F., Tesche, M., and Wiegner, M.: Heterogeneous ice nucleation in the ash plume of Eyjafjoll observed at two central-European EARLINET lidar sites, in: The 13th Conference on Cloud Physics/13th Conference on atmospheric Radiation (28 June-2 July 2010), AMS, Portland, USA, 2010.

Seinfeld, J. and Pandis, S.: Atmospheric Chemistry and Physics, Second edition, Wiley interscience pub, 2006.

Staudacher, T., Ferrazzini, V., Peltier, A., Kowalski, P., Boissier, P., Catherine, P., Lauret, F., and Massin, F.: The April 2007 eruption and the Dolomieu crater collapse, two major events at Piton de la Fournaise (La Reunion Island, Indian Ocean), J. Volcanol. Geotherm. Res., 184, 126-137, doi:10.1016/j.jvolgeores.2008.11.005, 2009.

Stevenson, D., Johnson, C., Collins, W., and Derwent, R.: The tropospheric sulphur cycle and the role of volcanic $\mathrm{SO}_{2}$, Geological Society special publication, 213, 295-305, 2003.
Suhre, K., Mari, C., Bates, T., Johnson, J., Rosset, R., Wang, Q., Bandy, A., Blake, D., Businger, S., Eisels, F., Huebert, B., Kok, G., Mauldin, R. I., Prévôt, A., Schillawski, R., Tanner, D., and Thornton, D.: Physico-chemical modeling of the First Aerosol Characterization Experiment (ACE 1) Lagrangian B, 1. A moving column approach, J. Geophys. Res., 103, 1643316455, 1998.

Sutton, A., Elias, T., Gerlach, T., and Stokes, J.: Implications for eruptive processes by sulphur dioxide emissions from Kilauea Volcano, Hawaii, J. Volcanol. Geotherm. Res., 108, 283-302 and 423-434, 2001.

Thomas, H., Watson, I., Carn, C. K. S., and Murray, S.: A multisensor comparison of sulphur dioxide emissions from the 2005 eruption of Sierra Negra volcano, Galapagos Islands, Remote Sens. Environ., 113, 1331-1342, doi:10.1016/j.rse.2009.02.019, 2009.

Tulet, P., Crassier, V., Solmon, F., Guedalia, D., and Rosset, R.: Description of the MESOscale NonHydrostatic Chemistry model and application to a transboundary pollution episode between northern France and southern England, J. Geophys. Res., 108(D1), 4021, doi:10.1029/2000JD000301, 2003.

Tulet, P., Crassier, V., Cousin, F., Suhre, K., and Rosset, R.: ORILAM, A three moment lognormal aerosol scheme for mesoscale atmospheric model, On-line coupling into the MesoNH-C model and validation on the ESCOMPTE campaign, J. Geophys. Res., 110, D18201, doi:10.1029/2004JD005716, 2005.

Winker, D. M., Pelon, J., and McCormick, M.: The CALIPSO mission: Spaceborne lidar for observation of aerosols and clouds, Symposium on Remote Sensing of the Atmosphere, Environment and Space, Hangzhou, China, 23-27 October 2002, 4893, 1-11, 2003.

Yang, K., Krotkov, N., Krueger, A., Carn, S., Bhartia, P., and Levelt, $\mathrm{J}$.: Retrieval of large volcanic $\mathrm{SO}_{2}$ columns from the Aura Ozone Monitoring Instrument (OMI): comparisons and limitations, J. Geophys. Res., 112, D24S43, doi:10.1029/2007JD008825, 2007.

Yang, K., Liu, X., Krotkov, N., Krueger, A., and Carn, S.: Estimating the altitude of volcanic sulfur dioxide plumes from space borne hyper-spectral UV measurements., Geophys. Res. Lett., 36, 1-6, 110803, doi:10.1029/2009GL038025, 2009. 